\title{
Bir Perakende İşletmesinde ERP Sistemi Üzerinden Satın Alma Ve Ödeme Döngüsünün Tasarımı*
}

\author{
Rauf MAMMADOV* \\ Banu Tarhan MENGI** \\ Sibel DOĞAN***
}

\section{ÖZET}

Her geçen gün kullanım alanı genişleyen ERP sistemleri, işletmenin satın alma ve ödeme süreci ile beraber birç̧ok iş sürecinin entegre olarak çalıştırlabilmesine imkân sağlamaktadır. Ancak iş süreçleri ile ilgili bilgi hacminin artması ve ERP sistemlerinin kurulumu sirasında gerekli iç kontrol ortamının yaratılmaması işletmeleri farklı hile riskleri ile karşı karşıya bırakmaktadır. Çalışmada perakende sektöründe faaliyet gösteren bir firma için ERP sistemi üzerinden uygun satın alma ve ödeme döngüsü prosedürü tasarlanmıstır. Satın alma ve ödeme sürecinin ERP sistemleri üzerinden nasıl işlediği anlatılmış olup, süreçte karşılaşılabilecek hata ve hileleri önlemede hangi kontrol önlemlerinin alınabileceği açıklanmaya çalışılmıştır.
\end{abstract}

Anahtar Kelimeler: Satın Alma, Döngü, Perakende Sektörü, ERP.

JEL Sinıflandırması: M40, M42

\section{Design of Purchasing and Payment Cycle Through ERP System in a Retail Business}

\section{ABSTRACT}

ERP systems that expand their field of application with each passing day enable the enterprise to operate in an integrated manner the purchasing and payment process as well as many business processes. But the increase in the volume of information related to business processes and the lack of the necessary internal control medium during the installation of ERP systems expose enterprises to different risks of frauds. In this study, an appropriate purchasing and payment cycle procedure has been designed through ERP system for a company operating in retail sector. It has been explained how the purchasing and payment process works through ERP systems and it has been tried to explain which control measures can be taken to prevent wrongs and frauds in the process.

Keywords: Purchase, Cycle, Retail Sector, ERP.

Jel Classification: M40, M42

* Makale Gönderim Tarihi: 22.10.2019, Makale Kabul Tarihi: 22.11.2019, Makale Türü: Örnek Olay (Vaka) Çalışması

* Marmara Universitesi, Sosyal Bilimler Enstitüsü, raufmmmdv@gmail.com, ORCID ID: 0000-0003-35611357.

** Doç.Dr., Marmara Üniversitesi, İşletme Fakültesi, Muhasebe Finansman Anabilim Dalı, btarhan@marmara.edu.tr, ORCID ID: 0000-0002-1803-8125.

*** Arş. Gör., Marmara Üniversitesi, İşletme Fakültesi, Muhasebe Finansman Anabilim Dalı, sibel.dogan@marmara.edu.tr, ORCID ID: 0000-0002-4707-1805. 


\section{GİRiş}

Günümüzde, işletmelere yönelik yapılan hile eylemleri tüm dünyada önemli bir sorun olarak görülmektedir. İşletmelerde yapılan hileler hem sıklık açısından hem de tutarsal açıdan giderek artmaktadır. Hilenin önlenmesine yönelik yapılan çalışmalar ise hileleri kesin olarak ortadan kaldıramamıştır. Bu durumun en önemli nedenlerinin biri işletmelerdeki etkin bir iç kontrol sisteminin olmamasıdır.

Kurumsal kaynak planlaması farklı sektörlerdeki firmaların, satın alma ve ödeme döngüsü ve diğer tüm süreçlerinin bütünleşik hale getirildiği sistemlerdir. Bu sistemlerle firmalar, yaptıkları farklı süreçlerle ilgili işlemleri tek bir sistem üzerinden sağlayabilmekte ve yönetimsel açıdan birçok rapor ve özet bilgiye rahatlıkla ulaşabilmektedirler. ERP yazılımları firmalar için oldukça kullanışlı ve faydalı sistemlerdir.

Çalı̧̧mada, işletmedeki en önemli iş süreçlerinden bir tanesi olan satın alma ve ödeme süreci incelenmiştir. Firmanın satın alma ve ödeme sürecindeki zayıf ve eksik yönleri tespit edilmiş ve ERP sistemleri üzerinden iyileştirilmesi için çözüm önerileri sunulmuştur.

Uygulama çalışması Türkiye'nin birçok ilinde faaliyet gösteren bir perakende işletmesinde yürütülmüştür. İşletmenin satın alma, mali işler, idari işler, reklam ve pazarlama, teslim alma ve muhasebe departmanlarından toplam yedi üst ve orta düzey yöneticiyle yüz yüze görüşme yapılmıştır. Ayrıca dosyalar, politika ve prosedürler, belgeler ve kullanılan bilgi sistemleri uygulamalarına iliş̧in erişim yetkileri gözden geçirilmiştir. Yapılan görüşmeler birebir soru cevap şeklinde gerçekleşmiş ve gerekli görülen konularla ilgili veri alınarak incelenmiş ve buna göre öneriler tasarlanmıştır. İşletme tarafindan sağlanan ve çalışmamıza temel teşkil eden bilgilerin doğru olduğu varsayımıyla hareket edilmiştir.

\section{KURUMSAL KAYNAK PLANLAMASI (ERP)}

\subsection{ERP Tanımı Ve İçeriği}

ERP, kurumsal kaynak planlaması anlamına gelen "Enterprise Resource Planning" kelimesinin kısaltmasıdır. Zorlu bir rekabet ortamının mevcut koşullarında hayatta kalmak ve planlama aşamalarını en doğru şekilde yapabilmek için firmalar bilgi teknolojilerinden yararlanmaktadır (Karateke, 2016: 3).

ERP için birçok farklı tanım bulunmasına rağmen, genel olarak tüm bilgi akışlarının entegre edilmesini sağlayan ticari yazılım paketleri olarak tanımlanabilir (Aydoğan, 2008: 109). ERP, işletmelerin kaynaklarını en doğru ve verimli şekilde kullanmalarını sağlar. Böylece işletmeler gereksiz kaynak tüketimini önleyerek, karlarını ve üretkenliklerini artıracaktır.

ERP sistemleri; üretim, satış, insan kaynakları, bütçe ve satın alma gibi birimlerin arasında tüm veri ve bilgi akışının entegre edildiği yazılım paketleridir (Aydoğan, 2008: 108). ERP bütünleşik, kapsamlı bir yapıya sahip büyük ve pahalı bir kurumsal sistem olup, organizasyonun iç ve dış değer zincirini en uygun hale getiren, optimize eden bir uygulamalar setidir. 
ERP; bünyesinde bulunan çeşitli fonksiyonları bir arada tutmak ve tek merkezden yönetmek için bilgisayar teknolojilerini kullanan bir sistemdir. Bütün iş süreçlerine, değer zincirine ulaşarak bütün departmanları, fonksiyonları tek bir bilgisayar sistemiyle bütünleştirmektir. Müşteri taleplerini en uygun şekilde karşılayabilmek için farklı coğrafi bölgelerde bulunan tedarik, üretim ve dağıtım kaynaklarının en etkin ve verimli bir şekilde planlanması, eşgüdümü ve kontrol edilmesini sağlayan yazılım sistemidir (Karagöz, Yıldız, Uzun ve Özaygün, 2014: 9-10).

Şekil 1'de de görüldüğü üzere ERP, şirketlerin tüm fonksiyonlarını tek noktadan yönetmeye yarayan bir sistemdir:

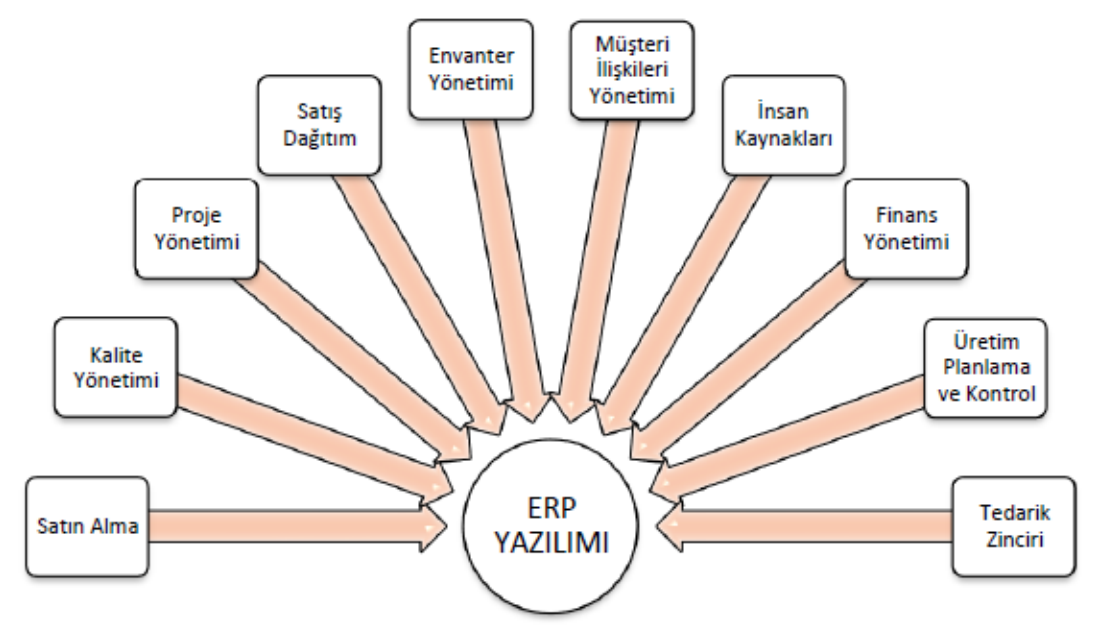

Şekil 1. Kurumsal Kaynak Planlama

Kaynak: Keçek ve Yıldırım (2010:195)

\subsection{ERP Sisteminin Özellikleri Ve İşletmeye Faydaları}

İşletmelerin büyüklüğüne ve bulunduğu sektöre göre ERP sisteminin özellikleri değişiklik göstermektedir. 141).

Sistemin temel özellikleri aşağıdaki şekilde özetlenebilir (Rosemann ve Gable, 2000:

- $\quad$ ERP sistemi, sektöre göre değişiklik gösterip, işletmelerin yapısı ve türüne göre kurulan standart yazılımdır.

- Diğer yazılım paketleri ile mukayese edildiği zaman daha rahat özelleştirilebilen yapısı vardır. tabanına sahiptir.

ERP sistemi, iş akışları ve ana verileri bir araya getiren bütünleşik veri

- $\quad$ İşa akışları hakkında çeşitli çözümler sunmaktadır. tasarlanmıştır.

Ülke ve bölgelerden bağımsız olarak çeşitli problemleri çözmek üzere 
- $\quad$ ERP sistemi, geniş işlevselliğe sahip olması sayesinde belirli sektörler değil tüm sektörler üzerinde kullanılabilen yapıya sahiptir. yazılımı değildir.

ERP sistemi bir uygulama yazılımı olup, bir veri tabanı yönetimi ve ara katman kapsamaktadır.

İşletme içerisinde belirli birkaç iş sürecini değil, tüm iş süreçlerini

Sistemin işletmelere sağladığı faydalar ise aşağıdaki gibidir (Bayraktar ve Efe, 2006: 705).

- $\quad$ Stok maliyetlerinin azalmasına katkıda bulunmaktadır.

- $\quad$ Maliyet analizlerinin doğru oluşturulmasını sağlamaktadır.

- Sürekli değişen üretim koşullarına zamanında tepki göstererek rekabet gücünü arttırmaktadır.

- $\quad$ Müşteri memnuniyetinin yükselmesini sağlamaktadır.

- Farklı ülkelerde faaliyet gösteren firmalar arasında ortak bir koordinasyon yaratarak birçok olumsuz etkeni ortadan kaldırmaktadır.

- İhtiyaç duyulan bilgiye doğru ve hızlı bir şekilde kolaylıkla erişilebilmektedir.

- $\quad$ Ortaya çıkan tehditlere daha hızlı tepki vermektedir.

- $\quad$ Lojistik hataların düşük seviyede tutulmasını sağlamaktadır.

\subsection{ERP Sisteminin Modülleri}

ERP sistemleri birçok modülü aynı çatı altında birleştirerek işletmelerin ihtiyaçlarını karşılamaktadır. Modüllerin birbirlerine bağlı olmadan kurulabilmesine karşılık, hepsi birleşik bir yapı içerisinde çalışmaktadır. Modüller işletme birimleri arasında entegrasyon sağlayan, bilgi alışverişini kolaylaştıran, şirketin tedarikçileriyle iletişimini sağlayan, çalışanlara gerekli bilgilere hızlı bir şekilde erişme olanağı tanıyan işlevsel yapılardır.

Bir işletme ERP sistemi kurmaya karar verdiği zaman 3 farklı seçenek ile karşılaşacaktır (Demirci, 2017: 60).

- Tek bir firma tarafindan tüm ERP paketinin kurulumu,

- Farklı firmalardan ERP modüllerinin temini,

- $\quad$ ERP sisteminin firmanın kendi bünyesinde geliştirmesi.

Firmalar için yukarıda belirtilen yöntem seçimi hem maliyet hem de rekabet gücü açısından çok önemlidir.

ERP sistemleri esas olarak firmaların kendi iş akışlarını yönetmek için geliştirilmiş ve daha sonra firmaların artan gereksinimlerine uygun olarak çeşitli sistemlerle entegre edilmiştir. ERP sistemleri birçok modülü kendi içinde barındırır. Bu modüller, kendi içlerinde ortak veri tabanlarıyla birbirine bağlanan çok işlevsel yapılara sahiptir. ERP sisteminin temel modülleri Şekil 2 'de gösterilmektedir. 


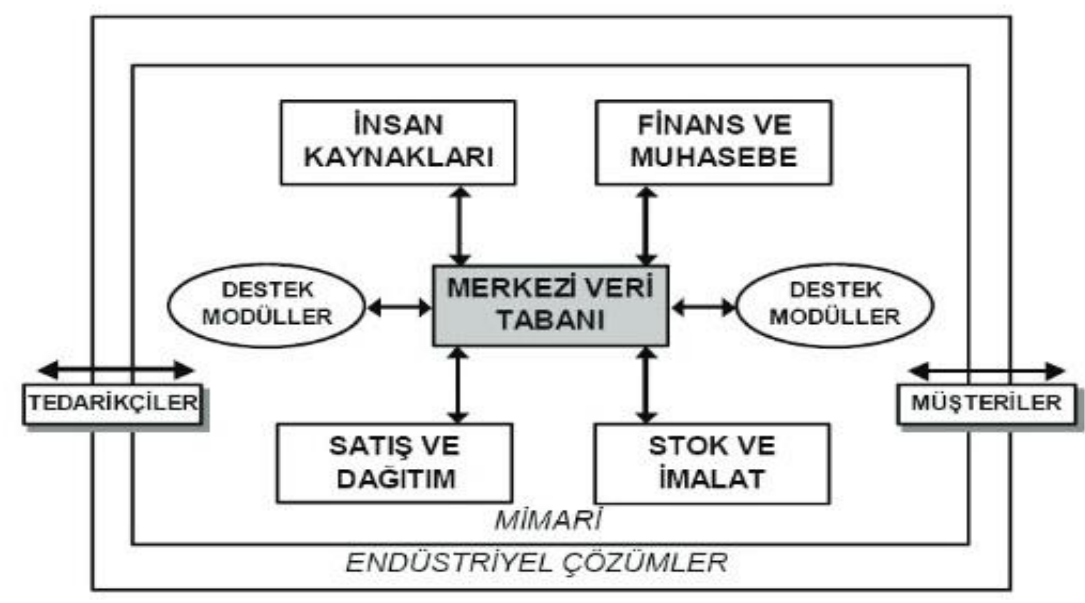

Şekil 2. ERP 'nin Temel Modülleri

Kaynak: Aydın, (2007 : 29)

\subsubsection{Malzeme İhtiyaç Planlama Modülü}

Malzeme ihtiyaç planlaması modülü hem ürünlerin hem de ürün dışındaki diğer kaynakların planlamasını sağlamaktadır. Ayrıca, planlama faaliyetleri yürütülürken, tüketim, talep tahmini, satış bütçesi, sipariş talepleri, sipariş emirleri, envanter, üretim emirleri gibi belirleyici ihtiyaçla da dikkate alınır (Yontar, 2014: 76).

$\mathrm{Bu}$ modül işletmelerin en önemli ve karmaşık ihtiyaçlarına cevap verebilir ve aynı zamanda çok şubeli iş süreçlerinde kullanılabilir. Malzeme ihtiyaç planlaması modülü sisteminin diğer modülleri ile entegre olarak çalışmaktadır. Entegrasyona dahil olan bütün modüller malzeme ihtiyaç planlaması için anlık veri üretmekte, böylelikle MRP sisteminin daima güncel kalmasına destek olmaktadırlar.

Malzeme ihtiyaç planlama modülünde bulunan temel özellikler aşağıdaki gibidir

( http://thalesbilisim.com/malzeme-ihtiyac-planlamasi/, 2019):

- $\quad$ Tesise dayalı ihtiyaç planlaması

- $\quad$ Çok boyutlu veri görüntüleme

- $\quad$ Verilerin grafiksel takibi

- $\quad$ Tesise dayalı olarak planlama emirlerinin hazırlanışı

\subsubsection{Satın Alma Modülü}

ERP'nin bu modülü, firmalara mal veya hizmet sunan diğer işletmeler ile aralarındaki tüm ticari faaliyetleri yapmak için gerekli veriler içeren bir modüldür. ERP'nin diğer modülleri ile entegre olan bu modül sayesinde firmalar stok girişi oluşturulmuş ürün bilgilerine anında erişim sağlayabilir ve gerekli malzemelerin temin etme süreçlerini kısa süre içerisinde gerçekleştirirler (Demirci, 2017: 63). 


\subsubsection{Satış Ve Dağıtım Modülü}

Satış ve Dağıtım Modülü, satış öncesi aktivitelerinden başlayarak satış, sevkiyat ve faturalamaya kadar devam eden iş süreçlerini kapsar.

$\mathrm{Bu}$ modül, diğer modüllerdeki süreçler için ihtiyaç duyulan bilgi akışını oluşturmak ve birbirleriyle etkileşimde bulunmak için kullanılan 2 alt modülü kapsamaktadır. $\mathrm{Bu}$ modüllerden ilki olan satış modülü, firmaların uzun vadeli ve kısa vadeli satış politikalarına uygun olarak tanımlanan hedefleri gerçekleştirmek için kullanılan bileşenleri içermektedir. Sipariş yönetimi, satış yönetimi, ürün fiyatlandırma, ürün kampanyaları, pazar fiyatı araştırmaları bu bileşenlere örnek verilebilir. İkinci bileşen olan dağıtım modülü, ürünlerin dağıtımına yönelik tüm süreçleri değerlendirir ve etkin şekilde uygulanmasını sağlar (Aydın, 2007: 30).

ERP sistemindeki diğer modüllerle entegre olan bu modülde, siparişlerle ilgili anlık bilgiler görüntülenebilmektedir. Siparişler ile ilgili detaylı bilgi veren bu modülde sunulan esnek fiyatlandırma özelliği kullanılarak, müşterilere özel fiyatlandırma ve indirimler uygulanabilir.

Satış Dağıtım modülünde bulunan temel özellikler aşağıdaki gibidir (https://sdmodulunegiris.com/satis-ve-dagitim-modulu-ne-yapar/ , 2019):

- $\quad$ Müşteri ana veri yönetimi,

- $\quad$ Teklif verme ve teklif takip süreçleri,

- $\quad$ Müşteri sözleşmelerin takibi,

- İndirim anlaşmaları,

- Satış kampanyaların hazırlanması ve takibi,

- $\quad$ Prim çalışmaları,

- Ürün kataloglarının hazırlanması,

- $\quad$ Bedelsiz malzemelerin satış süreci,

- $\quad$ Lojistik yönetimi,

- $\quad$ İade süreçleri,

- $\quad$ Sipariş maliyetlerinin takibi,

- $\quad$ Rakip ürün bilgilerinin takibi,

- $\quad$ Konsinye süreci,

- $\quad$ Hizmet ve servis satış1,

- $\quad$ Promosyon çalışmaları.

\subsubsection{Muhasebe Ve Finans Modülü}

ERP'nin en önemli modüllerinden bir tanesi de muhasebe ve finans modülüdür. Bu modül, tüm finansal verilerin takibini; tüm kayıtların sürekli olarak doğru bir şekilde tutulmasını, yatırım faaliyetlerinde kısa, orta ve uzun vadeli süreçlerde doğru karar verilmesi ve ödeme planlarının etkin bir şekilde yönetilmesini sağlar (Polat, 2013: 34).

Muhasebe ve finans modülünde bulunan temel özellikler ise aşağıdaki gibidir (Yıldız ve Akaydın, 2012: 7): 
- $\quad$ Birden fazla müşteri ile çalışabilme yeteneği,

- $\quad$ İşletmeye özel ticari işlemlerin kontrol edilmesi,

- $\quad$ Birden fazla para birimi ile çalışabilme yeteneği,

- $\quad$ Ödenmemiş hesap kalemlerinin kontrolü,

- $\quad$ Maliyet kalemlerinin yönetimi,

- $\quad$ Evrak girişlerinin rahat yapılması,

- $\quad$ Modülün birden fazla dil ile kullanılması,

- $\quad$ Arşivleme özelliğinin bulunması,

- Çeşitli raporların hazırlanması.

\subsection{5. Üretim Ve Stok Yönetimi Modülü}

Üretim ve stok yönetimi modülü, ERP sisteminin diğer modüllerinden daha geniş ve karmaşık yapıya sahiptir. Üretim modülü müşteriden siparişin kabul edilmesi, üretimin yapılması ve karşı firmaya tedarik edilmesine kadar olan tüm süreçleri kapsamaktadır (Yontar, 2014: 77). 2012: 8):

Üretim modülünde bulunan temel özellikler aşağıdaki gibidir (Yıldız ve Akaydın,

- $\quad$ Ürün ağaçlarının modüle aktarımı,

- Geniş standart planlama,

- Bütünleşik imalat için veri toplanması,

- $\quad$ Üretim aşamalarının takibi,

- Tam ve eksik parça listelerinin takip edilmesi,

- $\quad$ Maliyetlerin kontrol edilmesi,

- Güncel ve geçmişe yönelik stokların takibi,

- Müşteri siparişlerinin takip edilmesi,

- $\quad$ Üretim ağaçlarında değişiklik yapılabilmesi,

- $\quad$ Kalite yönetimi,

- $\quad$ Kapasite planlamas1.

Stok yönetimi modülü firma tarafından satın alınan ürünlerin depolara yerleştirilmesinden, müşteri firmaya iletilmesine kadar olan tüm süreçleri kapsamaktadır. Birden fazla deponun idare edilmesi, bakım için ayrı bir yere konulan ürünler, yapılan sayımların muhasebe modülüne aktarımı, parti ve seri numaralandırılmasının idare edilmesi, dönemsel stok sayımları, stok muhafaza birimlerinin kontrolü ve yönetimi, stok yönetimi modülünün temel özellikleri olarak sıralanabilir (Yıldız ve Akaydın, 2012: 9).

\subsection{6. İnsan Kaynakları Modülü}

İnsan kaynakları modülü, firmanın personeline yapılan ödemeleri, seyahat harcamaları, vardiya ayarlamaları, personeller ile ilgili eğitim harcamaları ve bordro yönetimi ile ilgili tüm verileri kaydetme imkanına sahiptir.

İnsan kaynakları modülünde bulunan temel özellikler aşağıdaki gibidir (http://thalesbilisim.com/insan-kaynaklari-yonetimi/, 2019): 
- $\quad$ İşletme çalışanlarının sicil bilgilerinin takip edilmesi,

- $\quad$ Ücret ayarlamalarının yapilmasi,

- Resmî kurumlara iletilmesi gereken formların oluşturulması,

- $\quad$ Puantaj kartlarının hazırlanmasi,

- Bordroların hazırlanması,

- İş tanımlarının oluşturulması,

- $\quad$ Kişisel özgeçmiş bankası yardımı ile işe alım sürecinin yönetilmesi,

- $\quad$ İşletme içi ve işletme dışı tüm eğitim taleplerinin ve planlarının incelenmesi,

- $\quad$ Firma çalışanlarının performans değerlendirilmesi,

- Çalışan self servis fonksiyonu sayesinde personellerin avans, izin, fazla mesai, ödül, PDKS takiplerini daha rahat izlemeleri ve insan kaynakları departmanı ile sürekli iletişim kurulması,

- $\quad$ Yönetici self servis fonksiyonu aracılığı ile bir yöneticinin kendisine bağl1 çalışanlarının bilgilerine ulaşabilmesi, onlardan gelen taleplerin değerlendirilmesi, izin onaylarının ve performans puanlarının verilmesi.

\section{X ISSTETMESINDE ERP SISTEMI ÜZERINDEN SATIN ALMA VE ÖDEME DÖNGÜSÜNÜN TASARIMI}

\section{1. İşletme Hakkında Genel Bilgiler}

Perakendecilik sektöründe önemli yere sahip olan X İşletmesi geçen yıllar içerisinde İstanbul dışındaki illerde de birçok mağazasını sektöre kazandırmış ve bu hızlı yükselişi ile 2018 sonunda toplam yüzden fazla mağazaya ulaşmıştır. Sebze ve meyve, et ve tavuk, şarküteri, taze gıdalar, kuru gıda, temizlik, kişisel bakım, gıda dışı ürünler kategorilerine yer verilen mağazalarda, ürün grubu ve çeşitliliği her geçen gün artmaktadır. X İşletmesi, bünyesinde yaklaşık 3000'e yakın personel istihdam etmektedir.

\subsection{Satın Alma Ve Ödeme Döngüsünün ERP Temelli İncelenmesi}

\subsection{1. İşletmenin Satın Alma Yapısının İncelenmesi}

Satın alma süreci işletmeden para çıkışına neden olan ve bu nedenle her şirket için önemli ve aynı zamanda riskli süreçlerden biridir. İşletmede satın alma yapısının doğru şekilde yapılandırılmaması ve satın alma süreçleri olan talep-sipariş-teklif-sipariş-teslim alma ve faturalandırma süreçlerinde belli bir ölçüde entegrasyon olmaması işletmeleri çeşitli hile türleri ile karşı karşıya bırakmaktadır.

Aşağıda işletmenin satın alma yapısının mevcut durumu ile ilgili bilgiler ve tarafımızca yapılan inceleme sonucu önerilerimiz yer almaktadır:

İşletmede ERP temelli bir program kullanılmaktadır. İlgili departmanda üst kademe olarak satın alma direktörü ve üç satın alma müdürü görev yapmaktadır. Satın alma ve depo bölümleri ayrı personellerden oluşmakla beraber her iki bölüm de birbirinden bağımsız şekilde çalışmaktadır. 
Soru 1: Satın alma bölümü’nün organizasyon yapısı ne şekildedir? Satın alma bölümü organizasyon şemasında kime bağlıdır?

İşletmede Var Olan Durum: İşletmede bağımsız bir satın alma bölümü bulunmaktadır. Satın alma direktörü ve kendisine bağlı çalışan 3 tane müdür bulunmaktadır. Her müdürün altında da satın alma kategorilerine yönelik çalışan personeller bulunmaktadır. Satın alma direktörü doğrudan genel müdür'e bağlıdır. Teslim alma süreci depo, faturalama süreci ise muhasebe bölümü tarafından yürütülmektedir. İşletmenin satın alma kategorileri aşağıdaki gibi gruplanabilir:

1. Ticari mal alımları (Mağazalarda satılan her türlü ürün),

2. Demirbaş alımları (Genel merkez ve mağaza demirbaşları),

3. Hizmet alımları,

4. Diğer alımlar (temizlik, kırtasiye vs.).

Ticari mal kapsamındaki tüm alımlar satın alma bölümü tarafından yapılmaktadır. Reklam ve pazarlama ilgili tüm malzeme ve hizmet alımları ise reklam ve pazarlama bölümü tarafından yapılmaktadır. Bu kapsam dışında kalan demirbaş, temizlik kırtasiye ve diğer tüm mal ve hizmet alımları idari işler bölümü tarafından yapılmaktadır.

Uygun Olan Kontrol Ve Öneriler: İşletmedeki satın alma organizasyonunda değişiklik yapılmasına ihtiyaç vardır. Çok spesifik mal ve hizmetler haricindeki tüm alımların satın alma bölümü tarafından yapılması daha doğru olacaktır.

İdari işler bölümü tarafindan yapılan düşük tutarlı harcamalar haricindeki diğer alımlar, uygun bir satın alma süreci tanımlanarak satın alma bölümü’ne devredilebilir.

Reklam ve pazarlama bölümü tarafindan yapılan reklam ve pazarlama alımlarının da satın alma bölümü'ne geçirilmesinde bir sakınca bulunmamaktadır. Alınması gereken ürünün nitelikleri, fiyatı, önceden alım yapılan yerler gibi temel bilgiler, reklam ve pazarlama bölümü çalşsanı tarafından satın alma bölümüne iletilmelidir. Bu alımlarda da satın alma bölümü tarafından standart satın alma süreci uygulanmalıdır.

Soru 2: Satın alma sürecine yönelik herhangi bir prosedür ya da yönetmelik var mı?

İşletmede Var Olan Durum: İşletmede yazılı prosedür veya yönetmelik tarzı bir doküman bulunmamaktadır. Yöneticiler tarafından mail üzerinden yapılan çeşitli bildirimler mevcuttur. Daha önce taslak bir prosedür hazırlandığı belirtilmiş ancak ilgili prosedür nihai hale getirilmemiş ve yayınlanmamıştır.

Uygun Olan Kontrol Ve Öneriler: Politika ve prosedürler hilenin önlenmesinde faydalı bir dokümandır. Bu kapsamda satın alma sürecine yönelik üst yönetim tarafından belirlenen kurallar yazılı hale getirilmelidir. İlgili prosedüre tüm ilgili çalışanlar erişebilmelidir. Prosedürün güncel kalmasının sağlanması da bu kapsamda dikkat edilmesi gereken bir noktadır. 
Soru 3: Satın alma sürecinde görevlerin ayrllı̆̆ ilkesine uygun olmayan durumlar var $\mathrm{m} 1 ?$

İşletmede Var Olan Durum: Ticari mal alımları satın alma müdürlerine bağlı çalışan personeller tarafından yapılmaktadır. Stok takibi ve sipariş işlemleri ilgili çalışanlar tarafından yapılırken teslim almalar ise depo tarafindan yapılmaktadır. Ticari ürün alımlarında satın alma işlevinin yanında satışa yönelik faaliyetler de yürütülmektedir. Satış fiyatını belirleme, kampanya ve iskontolar, ürün hareketlerinin yönetimi de bu bölüm tarafindan sağlanmaktadır.

İdari işler bölümünün yaptığı diğer mal ve hizmetler kapsamındaki satın almalarda teklif ve sipariş süreçlerinde görevlerin ayrılığı tam olarak uygulanmamakta olup tek bir kişi üzerinden yürütülmektedir.

Reklam ve pazarlama kapsamında yapılan alımlarda ihtiyaç belirleme, teklif ve sipariş verme süreçleri aynı personel tarafından geçekleştirilmektedir. Bu kapsamdaki alımlarda da görevlerin ayrılığ 1 ilkesi uygulanmamaktadır.

Tablo 1. Malzeme Gruplarına Göre Satın Alma Süreci

\begin{tabular}{|l|l|l|l|l|l|}
\hline \multicolumn{1}{|c|}{ Malzeme Grubu } & \multicolumn{1}{|c|}{ Talep } & \multicolumn{1}{|c|}{ Teklif } & \multicolumn{1}{c|}{ Sipariş } & $\begin{array}{c}\text { Teslim } \\
\text { Alma }\end{array}$ & \multicolumn{1}{c|}{ Faturalama } \\
\hline Ticari Mal Alımları & Mağazalar & Satın Alma & Satın Alma & Depo & Muhasebe \\
\hline Demirbaş Alımları & $\begin{array}{l}\text { Merkez / Mağaza } \\
\text { Çalışanları }\end{array}$ & İdari İ̧̧ler & Satın Alma & Depo & Muhasebe \\
\hline $\begin{array}{l}\text { Reklam ve } \\
\text { Pazarlama Alımları }\end{array}$ & Reklam ve Pazarlama & $\begin{array}{l}\text { Reklam ve } \\
\text { Pazarlama }\end{array}$ & $\begin{array}{l}\text { Reklam ve } \\
\text { Pazarlama }\end{array}$ & Depo & Muhasebe \\
\hline $\begin{array}{l}\text { Diğer Mal ve Hizmet } \\
\text { Alımları }\end{array}$ & İtiyaç Sahipleri & İdari İ̧̧ler & İdari İler & Depo & Muhasebe \\
\hline
\end{tabular}

Uygun Olan Kontrol Ve Öneriler: Görevlerin ayrılığı gerek hata gerekse de hilenin önlenmesinde çok kritik işleve sahiptir. Bu kapsamda önemli olan kritik görevleri baştan sona tek bir kişinin yapmasının önlenmesidir. İşletmenin satın alma faaliyetlerini görevlerin ayrılığı açısından değerlendirildiğinde ve diğer mal ve hizmet kategorisi alımlarında aynı kişinin hem teklif hem de sipariş verme süreçlerinin, reklam ve pazarlama alımlarında ise talep, teklif ve sipariş süreçlerinin ayni personeller tarafından yapılması büyük risk taşımaktadır. Soru 1'de belirttiğimiz yapı uygulandığı takdirde görevlerin ayrılığı sağlanmış olacaktır.

Soru 4: Sistemde uygun erişim ve yetki tanımlamaları yapılmış mı?

İşletmede Var Olan Durum: Yetkiler satın alma kategorilerine göre ayrıştırılmıştır. Her alt kategori aynı kullanıcı ve şifreyi kullanmaktadır.

Açılan sipariş üzerinde fiyat değişikliği yapılamamakta, teslim alma gerçekleşene kadar sipariş sahibi tarafından miktar üzerinde değişiklik yapılabilmektedir. Açılan sipariş̧ bir başka kişi tarafından değiş̧tirilememekte ancak bazı durumlarda ek sipariş̧ açılabilmektedir. 
Sistemden yetki tablosu temin edilmiştir. Daha önce firmada çalışıp, mevcut durumda başka bir yerde çalışan kişilerin hala satın alma modülüne erişebildiği görülmüştür.

Uygun Olan Kontrol Ve Öneriler: Bu konudaki genel gözlem, satın alma yapan her alt kategori personeli için ayrı kullanıcı adı ve şifre kullanılması yönündedir. Ayrıca işten ayrılan personellerin kullanıcı adı ve şifresi iptal edilmelidir.

Soru 5: Satın alma süreci belirlenen bütçelere göre yürütülüyor mu?

İşletmede Var Olan Durum: İşletmede hazırlanan bir bütçe vardır. Ancak bütçe manuel olarak takip edilmektedir. Sisteme tanımlı herhangi bir parametre bulunmamaktadır.

Uygun Olan Kontrol Ve Öneriler: Hazırlanan bütçe kalemlerinin ERP sistemine tanımlanması, ilgili malzeme grubundan sipariş verildikçe bu bütçeden otomatik düşüm yapılması önerilir. Belirlenen bütçe aşıldığında, sipariş açılmasını engelleme, ek onaya tabi tutma veya engelleme olmadan, belirlenen yöneticilere bilgilendirme yapılması gibi önleyici kontrol noktaları oluşturmak firma için daha faydalı olacaktır.

\subsubsection{Satın Alma Ve Ödeme Döngüsünün Süreç Bazında İncelenmesi}

\subsubsection{Satın Alma Talebinin Oluşturulması}

Soru 1: Satın alma talebinin oluşturulması ve onay süreci nasıl işlemektedir?

\section{İşletmede Var Olan Durum:}

1.Ticari Mal: Ticari mal alımları bütçe doğrultusunda yapılmaktadır. Bu nedenle standart bir talepte bulunma ve talep onay süreci yoktur. Bazı durumlarda mağazalardan çeşitli talepler gelebilmektedir. Her mağazada aynı ürün satılmadığı için mağazaların kendilerinde bulunmayan bir ürünü talep ettiği durumlar da yaşanabilmektedir. Mağazalar tarafından yeni ürün talebi ERP programı aracılığı ile satın alma bölümüne iletilmektedir. Satın alma direktörü tarafından ürünün alınmasının gerekli olup olmadığına göre karar verilerek ürün alımı sözlü olarak onaylanmaktadır.

2.Demirbaș: Merkez ya da mağaza çalışanları tarafindan kâğıt üzerinde talep formu oluşturularak mail ortamında idari işler müdürü 'ne gönderilir. Talep formunun çıktısı alınıp, mali ve idari işler genel müdür yardımcısı tarafından onaylanmaktadır.

3. Hizmet: Reklam ve pazarlama ilgili hizmet alımları kapsamında reklam ve pazarlama bölümü personeli tarafindan ERP programı üzerinden talep formu oluşturulmaktadır. Talep formunun çıktısı alınarak reklam ve pazarlama müdürü tarafindan onaylanmaktadır. Bakım onarım, yemek, temizlik ve güvenlik hizmet alımları idari işler bölümü tarafından yapılmış olup herhangi bir talep oluşturma ve onay süreci bulunmamaktadır.

4. Diğer Alımlar: Yukarıdaki alımlar dışında kalan diğer malzeme alımlarının hiçbiri için ERP programı üzerinden talep açılmamaktadır. Talep formu matbu olarak düzenlenerek mail ortamında idari işler yöneticisi 'ne gönderilmektedir. İlgili talebe ilişkin formun çıktısı alınıp idari işler müdürü tarafından onaylanmaktadır. 
Uygun Olan Kontrol Ve Öneriler: İhtiyacın belirlenmesi ve satın alma talebinin oluşturulması, sürecin ilk aşaması olduğu için oldukça önemlidir. Bu aşamada yapılabilecek her türlü hata, takip eden diğer süreçlere de etki edecektir. Talep üzerine satın alması yapılan tüm mal ve hizmetler için talep-teklif-sipariş entegrasyonu sağlanması önerilir. Bu kapsamda yapılabilecek bazı öneriler şu şekilde olacaktır:

- $\quad$ ERP programı kullanan bir şirkette form çıktısı alarak imzalatma uygulaması olmaması gereken bir durumdur. Bunun yerine sistem üzerinden belirlenmiş kriterlere göre kademeli bir onay sistemi oluşturulmalıdır.

- Benzer şekilde mail ile yapılan taleplerin de ortadan kaldırılması ve sisteme adapte edilmesi önerilir.

- $\quad$ Talep oluşturma ve onay süreci bulunmayan hizmetler için ERP programı üzerinden satın alma talebi ve kademeli onay sistemi oluşturulmalıdır.

Aşağıda satın alma talebinin oluşturulması ile ilgili standart bir işleyiş kısaca anlatılmaktadır:

Farklı yerlerde kullanmak amacıyla işletmenin birden fazla lokasyonunda veya bölümünde aynı mal/hizmet talebi meydana gelebilir. Bu durumda indirim seçeneklerinden faydalanılması ve süreci daha rahat takip edebilmek adına, bu taleplerin satın alma bölümünde birleştirilmesi mümkündür. Talepler birleştirildikten sonra ilgili malzemeye yönelik stokta var olan miktar kontrol edilerek ihtiyaç belirlenir.

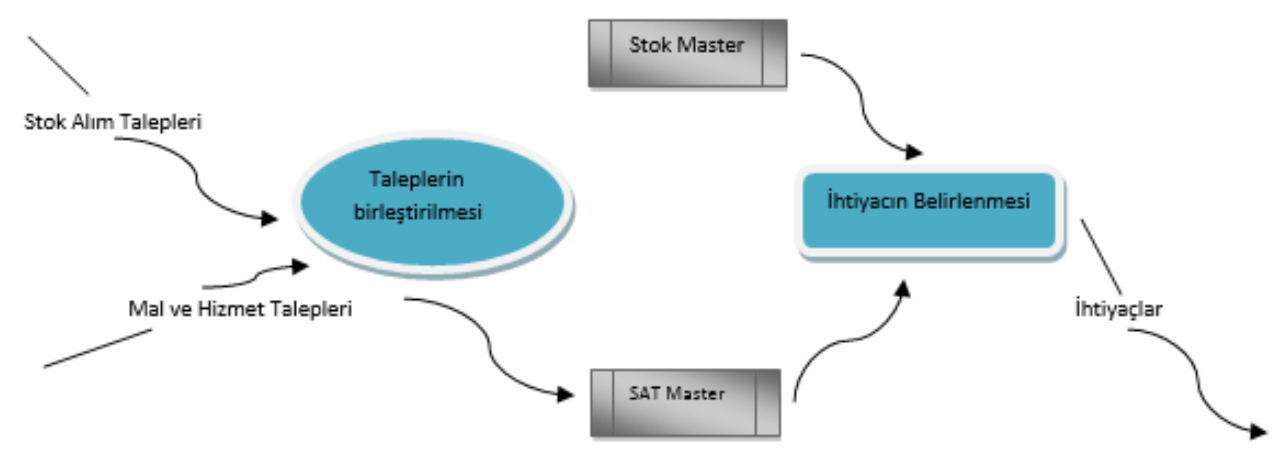

Şekil 3. İhtiyaç Belirleme Süreci

Kaynak: Gelinas, Jr. Ulric J, Richard B. Dull, (2008: 432)

\subsubsection{Teklif Alma Ve Değerlendirme}

Soru 1: Satıcılardan teklif alma ve değerlendirme süreci nasıl işlemektedir?

\section{İşletmede Var Olan Durum:}

1.Ticari Mal: Birden fazla şirketten fiyat teklifi alındığı durumlarda alım yapılacak firmayı satın alma direktörü belirlemektedir. Bütün satın alma işlemlerinin başlaması limit fark etmeksizin satın alma direktörünün onayına bağlıdır. Ancak genellikle marka bazlı alım yapıldığ 1 için tedarikçiler arasında seçim yapma durumu olmamaktadır. Hangi ürünün 
alınacağına öncelikli olarak karar verilir. Sonrasında ise hangi markadan alınacağına karar verilir. Bu kararlar satın alma komisyonunda görüşülür ve karara bağlanır.

2.Demirbaș: Önceden üç teklif alma zorunluluğu olmakla birlikte sonrasında bu uygulamadan vazgeçilmiştir. Sürekli alım yapılan birkaç tedarikçi bulunmaktadır. İdari İşler Yöneticisi tarafından teklif alınsa bile sisteme teklif girişi yapılmamaktadır. Hangi firmadan alım yapılacağı ile ilgili kararı mali ve idari işler genel müdür yardımcısı karar vermektedir.

3. Hizmet: Reklam ve pazarlama ilgili hizmet alımları için teklif süreci reklam ve pazarlama müdürü tarafından takip edilmektedir. En az üç teklif alınmaktadır. Teklif için mail atılır ve gelen teklifler karşılaştırmalı olarak genel müdür'e onay için sunulmaktadır. Diğer hizmetler için ise uzun süredir çalışılan tedarikçiler olup, yapılan sözleşmeye göre süreç ilerlemektedir.

4. Diğer Alımlar: ERP programı üzerinde teklif alma ve karşılaştırma süreci yürütülmemektedir. Teklifler genellikle maille alınmakta olup, alınacak malzemenin türüne göre sözlü olarak da alınabilmektedir. Hangi firmadan alım yapılacağı ile ilgili kararı mali ve idari işler genel müdür yardımcısı karar vermektedir.

Uygun Olan Kontrol ve Öneriler: Teklif alma ve değerlendirme süreci şu an tüm alım türleri için ERP programı dışında yürütülmektedir. Yapılan süreç incelemesi sonucunda tüm alımlar için teklif sürecinin sistemden yürütülmesi mümkündür.

$\mathrm{Bu}$ kapsamda şirketin kullandığı ERP programında bulunan teklif modülünün kullanılması sağlanmalıdır.

\subsubsection{Satın Alma Siparişinin Oluşturulması}

Soru 1: Tüm alımlar için zamanında sipariş formu açılıyor mu ve sipariş formu olmadan alım yapıldığı durumlar var mı?

\section{İşletmede Var Olan Durum:}

1.Ticari Mal: Depoya alınacak ürünler için ilgili satın alma yöneticisi tarafından satın alma siparişi düzenlenmektedir. Şirkette 25 günlük stokla çalışılmaktadır. Stok seviyeleri günlük olarak otomatik bir şekilde ERP programından maille gelen depo raporunda takip edilmektedir. 25 günlük stok bandında kalan siparişler satın alma yöneticileri tarafından verilmektedir. Bu seviyenin üzerinde verilecek siparişler için satın alma müdürü'nden sözlü onay alınmaktadır.

2.Demirbaș: $\mathrm{Bu}$ malzeme grubunda, sipariş mal geldikten sonra açılmaktadır. Malzeme teslim alınırken depo tarafından girişinin yapılabilmesi için sipariş açılmaktadır. İlgili irsaliye ilk olarak satın alma uzmanına iletilir. Gelen irsaliyeye göre sistemde sipariş oluşturulur ve irsaliyenin üzerine sipariş numarası yazılarak depoya iletilir. Depo gelen irsaliyeye göre sistem girişini yapar. Ancak bu sürenin uzaması ilgili malzemenin envantere girmeden kullanılmasına neden olmaktadır. 
3. Hizmet Alımları: Reklam ve pazarlama ile ilgili hizmet alımları için ERP programından sipariş oluşturulmaktadır. Yemek, temizlik, güvenlik ve diğer hizmetler için siparişler ERP programı üzerinden sonrasında açılmaktadır.

4. Diğer Alımlar: İhtiyaç duyulan malzemenin siparişi excel 'de oluşturulmaktadır. ERP programı üzerinde sipariş sonrasında açılmaktadır.

Uygun Olan Kontrol Ve Öneriler: Satın alma sipariş formu satın alma sürecindeki en kilit dokümandır. $\mathrm{Bu}$ nedenle bu konuya ilişkin son derece güçlü kontroller oluşturulmalıdır.

Ticari mal alım sürecinin tasarımında bu konuda önemli bir aksaklık bulunmamaktadır. Yalnız sözlü onay sisteminin de sistem onayı şekline çevrilmesi daha sağlıklı olacaktır.

Demirbaş alımlarının işleyişi uygun bulunmamış olup, bu alımlar için de önceden sipariş düzenlenmesi sağlanmalıdır. Benzer durum reklam ve pazarlama malzemeleri dışındaki hizmet alımları için de geçerlidir.

İdari işler bölümü tarafında yürütülen yukarıdaki alımlar dışındaki diğer alımlara ilişkin süreç ise bu alandaki en riskli uygulamanın bir örneğidir. Burada ticari alım sürecinin aynısının yürütülmesi önerilir.

Aşağıda satın alma siparişinin oluşturulması ile ilgili standart bir işleyiş kısaca anlatılmaktadır:

Satın alma siparişi, belirli ürün ya da hizmetlerin, belirlenen koşullarda tedarik edilmesi için satıcıya yapılan resmi taleptir. Satın alma siparişleri bir satın alma talebine, teklif talebine ya da başka bir satın alma siparişine referansla ya da hiçbir referans göstermeksizin yaratılabilir. Satın alma siparişi verilerini girerken, varsayılan değerleri sistem otomatik olarak önerir. Örneğin sipariş adresi, ödeme koşulları ve navlun koşulları, satıcı ana verilerinden önerilir. Söz konusu ürün için ürün ana verileri oluşturulmuş ise, sistem aynı zamanda ürün kısa metni ya da ürün grubu gibi bilgileri de önerir. Sistemde satın alma bilgi kaydı mevcut durumda ise, sistem buna dayanarak satın alma siparişine bir fiyat önerisi kopyalar. 


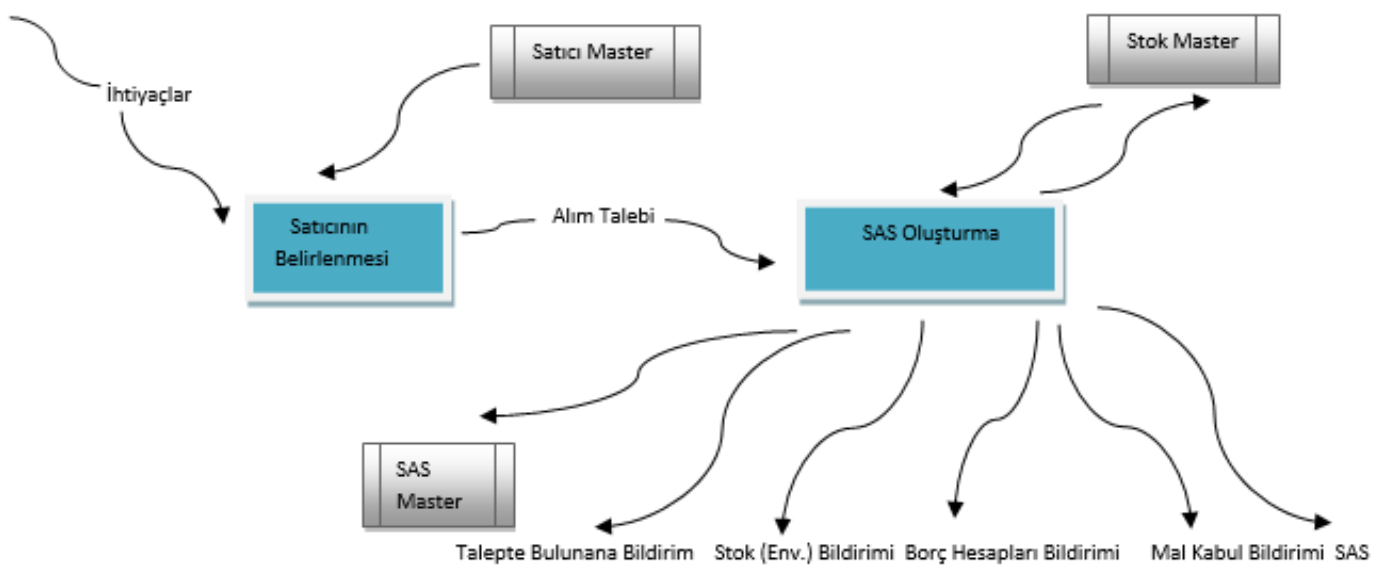

Şekil 4. SAS Oluşturma Süreci

Kaynak: Gelinas, Jr. Ulric J, Richard B. Dull, (2008: 433)

Soru 2: Sipariş formları satıcılara ne şekilde gönderilmektedir?

\section{İşletmede Var Olan Durum:}

Ticari Mal: Sipariş formu ERP programında oluşturulmaktadır. Sipariş oluşturulduktan sonra excel formatına çevrilmektedir. Excel formatındaki siparişe, ERP programı sipariş ekranında olmayan fiyat ve ıskonto bilgileri manuel olarak eklenmektedir. Oluşturulan excel formatındaki sipariş mail ile satıcıya gönderilmektedir.

Demirbaș: Bu kategorideki siparişler, satıcılara mail ortamında ve bazen de telefon aracıllğ 1 ile verilmektedir.

Ticari mal ve demirbaş dışındaki tüm alımlar ile ilgili siparişler satıcılara mail yolu ile verilmektedir. ERP programı bu kapsamda kullanılmamaktadır.

Uygun Olan Kontrol Ve Öneriler: Düzenlenen sipariş formları satıcılara uygun şekilde iletilmelidir. Sözlü bir şekil yapılan bildirimler yerine sistem üzerinden veya yazılı bildirimler yapılmalıdır. Yapılacak bildirimlerin olası aksaklıklarda işletme için kanıt sağlayıcı nitelikte olmasına dikkat edilmelidir. Bu kapsamda sistemde var olan aksaklıkların giderilmesi ve siparişin PDF formatına çevrilerek otomatik bir şekilde tedarikçiye gönderilmesi sağlanmalıdır.

Soru 3: Bekleyen siparişler periyodik olarak inceleniyor mu?

İşletmede Var Olan Durum: Bekleyen siparişlerin ilgili kategoriyi yöneten satın alma müdürleri tarafından aylık olarak kontrol edildiği ve kapatıldığı beyan edilmiştir. İlgili konuya yönelik kontrollerin gerçekleştirilmesi amacıyla satın alma raporu temin edilerek incelenmiş̧ir. Yapılan kontrolde termin tarihi geçmesine rağmen tamamı teslim alınmayan malzemeler olduğu görülmüştür. Bazı siparişler hiç teslim alınmamışken, bazılarında $\% 1$ oranında eksik teslimat gerçekleştirilmiştir. 
Uygun Olan Kontrol Ve Öneriler: Bekleyen siparişler, sonrasında uygun olmayan teslim alma işlemlerinin gerçekleştirilebilmesi için elverişli bir ortam oluşturmaktadır. Bu nedenle birikmiş eski açık kalan siparişlerin kapatılması sağlanmalıdır. Sonrasında ise bu şekilde açık kalan siparişlerin otomatik bir şekilde kapatılmasına yönelik uygulama geliştirilmelidir.

Soru 4: Satıcı sözleşmeleri uygun şekilde muhafaza ediliyor mu?

İşletmede Var Olan Durum: Sözleşmelerin asılları sistemde arşivlenmeyip matbu olarak muhasebe bölümü'nde muhafaza edilmektedir.

Uygun Olan Kontrol Ve Öneriler: Sözleşmelerin PDF formatına getirilerek ERP programı sisteminde arşivlenmesi önerilir. Sözleşmeler uygun şekilde muhafaza edilmeli ve ilgili olmayan kişilerin sözleşmelere erişimi kısıtlanmalıdır.

\subsubsection{Teslim Alma}

Soru 1: Gelen mallar ile ilgili teslim alma süreci nasıl işlemektedir?

\section{İşletmede Var Olan Durum:}

1.Ticari Mal: Merkez depoya gelen mallar barkodla okutularak teslim alınmaktadır. Siparişi olmayan bir malzemenin teslim alması yapılamamaktadır. Siparişi olan malzemelerde yüzde 10 oranında bir tolerans limiti belirlenmiş̧ir.

Merkez depoya toleransı aşan fazla mal geldiyse, ilgili satın alma çalışanı ile görüşülmektedir. Sözlü onay alınması halinde ek sipariş açılmakta ve mal kabul yapılmaktadır.

Mağazalara merkez depodan gelen ürünler tam olarak kontrol edilememektedir. İrsaliyeler ile ürünler fiziksel olarak değil de paletlerin üzerine yapıştırılmış olan etiketler üzerinden kontrol edilmekte, ancak o paletin içi tek tek kontrol edilememektedir. Eksik ya da fazla mal geldiği reyonda fark edildiğinde merkez depoya bilgi verilmektedir. İrsaliyede var ve gönderilen ürünlerin içinde yok ise ve durum fark edilirse rapor düzenlenerek merkeze gönderilmektedir. Eksik olan ürünler depo tarafindan ertesi gün gönderilmektedir.

2.Demirbaș: Gelen mallar irsaliye ile kontrol edilir ve fiziken teslim alınır. İrsaliye satın alma bölümüne gönderilir, burada ERP programı üzerinden sipariş açılır, irsaliyenin üzerine sipariş numarası yazılarak tekrar depoya gönderilir. Depo sorumlusu irsaliyeye göre ERP programında ilgili sipariş için mal kabulü yapar. Bu malzeme grubunda da tolerans $\% 10$ 'dur ancak irsaliyeye göre sipariş açıldığı için süreç çok kontrollü değildir.

3.Hizmet: Tüm hizmet alımlarında ERP sistemi üzerinden teslim alma yapılmamaktadır.

4.Diğer Alımlar: Diğer alımlar ile ilgili gelen mallar irsaliye ile kontrol edilir ve fiziken teslim alınır. İrsaliye, idari işler bölümüne gönderilir, burada ERP programı üzerinden sipariş açılır, irsaliyenin üzerine sipariş numarası yazılarak tekrar depoya gönderilir. Depo sorumlusu irsaliyeye göre ERP programında ilgili sipariş için mal kabulü yapar. 
Uygun Olan Kontrol Ve Öneriler: Bu konuya yönelik olarak yapılabilecek öneriler şu şekildedir:

- $\quad$ Ticari mal kapsamında toleransı aşan malzemeler için ek bir süreç yürütülmeli, bu tür malzemelerin kontrollü kabulü sağlanmalıdır. Ayrıca merkez depodan mağazalara gelen ürünler ile ilgili paletler tek tek kontrol edilmeli ve eksikliğin, ürünler reyona gitmeden önce tespit edilmesi gerekmektedir.

- Demirbaş ve diğer alımlar kapsamındaki ürünler için zamanında sipariş açılmalıdır. Bu konuda zaman kısıtlamasına gidilmesi önerilir. Teslim alma yapmadan belli bir zaman önce sipariş açılması engellenebilir. Böylece malzeme geldikten sonra sipariş açma ya da fazla gelen malzeme için ek sipariş açma uygulamaları kontrol altına alınmalıdır.

- Hizmet alımları ile ilgili malzeme teslim alması yapıldığı gibi, hizmet teslim alması da yapılmalıdır. Bu süreçte ortada bir mal ve irsaliye olmadığı için takip ve kontrolü daha zordur. Hizmeti talep eden personel sistem üzerinden hizmetin tamamladığı bilgisinin girişini yapmalıdır. Gerekirse bu süreç belirlenen hiyerarşide onaya tabi tutulabilir. $\mathrm{Bu}$ şekilde bir uygulama ile ödemesi yapılmadan önce hizmetin gerçekten teslim alındığı görülmüş olacaktır.

Aşağıda malların teslim alınması ile ilgili standart bir işleyiş kısaca anlatılmaktadır:

Teslim alma sürecinde öncelikle SAS (satın alma siparişi) üzerinden kontrol gerçekleştirilmelidir. Bu şekilde gelen malzemelerin, doğru olup olmadığı kontrol edilir. Daha sonra miktar kontrolünün gerçekleştirilmesi için malzemelerin sayılması veya tartılması gerekmektedir. Gelen malzemeler ile SAS'ta yer alan bilgilerin eşleşmemesi üzerine malzemelerin reddedilmesi veya şartlı kabul edilmesi söz konusu olabilir. Malzemeler uygun şekilde kalite kontrolden geçtikten sonra, sistemde "alış raporu" düzenlenmelidir. Bu raporun düzenlenmesinin temel amac1, yapılan teslim alma faaliyetini uygun şekilde belgelendirmektir.

Teslim alma faaliyetinin ERP kapsamında yaptı̆̆ işlemler ve yarattı̆̆ı bilgi akışı şekilde ifade edilmiştir. Bu aşamada gerçekleşen işlemler şu şekildedir:

\footnotetext{
- Malzemeler irsaliyesi ile birlikte işletmeye gelir. Sayım ve kalite kontrol gerçekleşir. düzenlenir.

- $\quad$ Bir sorun varsa malzemeler reddedilir, bir sorun yoksa kabul gerçekleşir.
- SAS ile karşı1laştırma sistemden yapılır. Açık SAS kapanır. Alış raporu

- $\quad$ Stok miktarı güncellenir. Muhasebede geçici hesaplar çalışır.

- Yapılan teslim alma faaliyeti, ilgili ana dosyalar bilgi kaydı atar.

- Depoya bildirim gerçekleşir.
} 


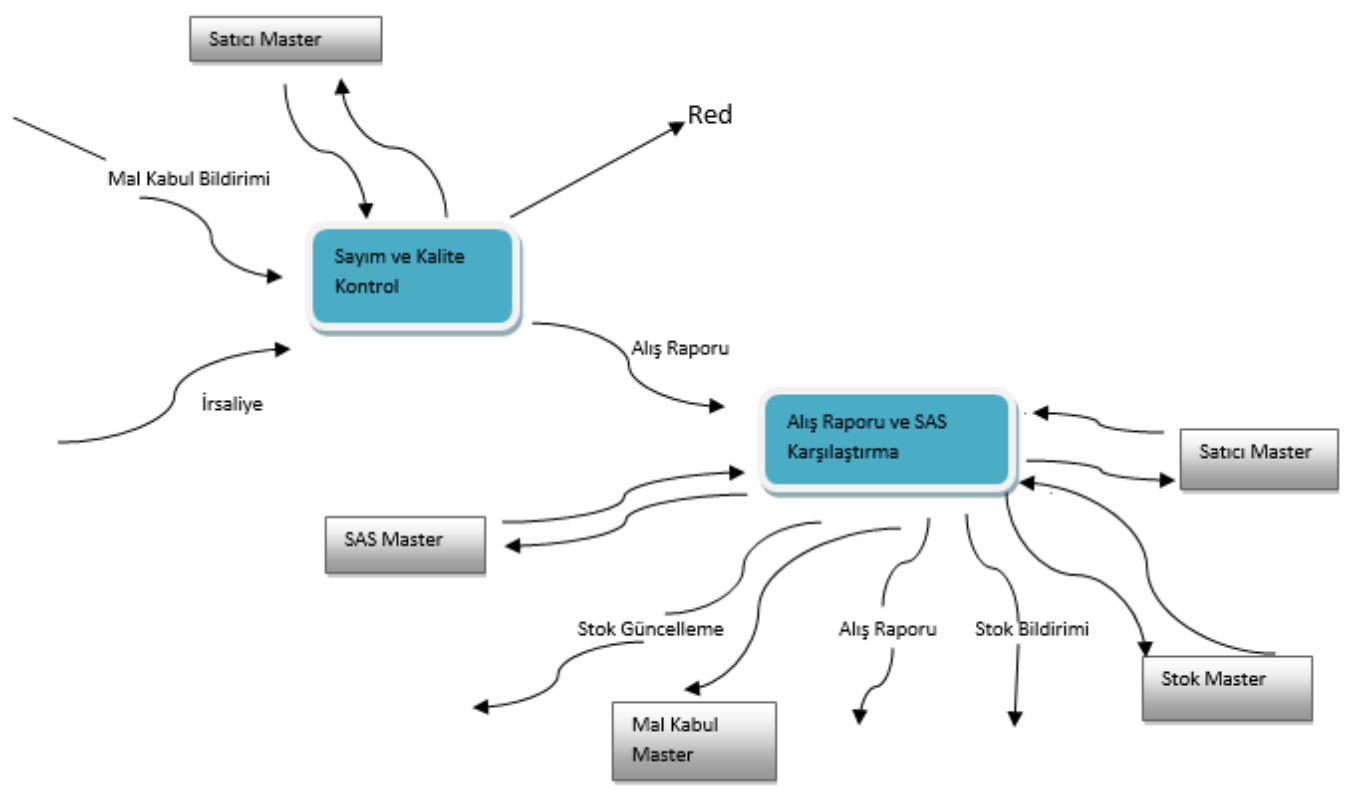

Şekil 5. Teslim Alma Süreci

Kaynak: Gelinas, Jr. Ulric J, Richard B. Dull, (2008: 435)

Soru 2: Gelen mallar ile ilgili şartlı kabul uygulaması süreci nası1 işlemektedir?

İşletmede Var Olan Durum: Şartlı kabul uygulaması gibi bir uygulama sistemde bulunmamaktadır. Ürünler için bir sıkıntı var ise teslim alma yapılmadan bekletilir. Genel Müdür tarafindan yazılı onay alındıktan sonra girişi yapılır. Bu süreç içerisinde ürünler sistemde görülmemektedir.

Bloke stok uygulaması sadece daha önceden teslim alması gerçekleştirilmiş ama SKT sinin dolması yakın olan ürünler için kullanılır ve ilgili ürünler fiziken de ayrı bir yere konularak satın alma bölümünün bu ürünleri görmesi engellenir. Bunun sebebi de satın alma bölümü ürünü stoklarda görmemesi içindir.

Uygun Olan Kontrol Ve Öneriler: Teslim alma yapmadan daha sonra kabul etmek üzere bekletilen malların şartlı kabul edilerek, bloke stoklara alınması önerilir. Bu şekilde mallar maliyet hesaplarını etkilemeden miktar olarak takip edilebilecektir.

\subsubsection{Faturalandırma}

Soru 1: Faturalar gerekli kontrollerden geçirilerek kayda alınıyor mu?

İșletmede Var Olan Durum: Ticari mal faturaları ilk önce satın alma bölümüne gelmektedir. Satın alma bölümü tarafindan faturalar, miktar ve birim fiyat yönünden kontrol edilerek onaylanmaktadır. Onaylanan faturalar talep formu ile birlikte muhasebe bölümüne iletilmektedir. Muhasebe bölümü faturayı ekleriyle birlikte ilgili alımı talep eden kişiye göndermektedir. Fatura, talepte bulunan kişi ve ilgili direktör tarafindan onaylanarak 
muhasebe bölümüne iletilir. Onayları tam olan faturanın girişi yapılır. Faturaların muhasebe bölümüne zamanında gelmediği bildirilmiş̧ir.

Ticari mal faturaları dışında kalan tüm mal ve hizmet alım faturaları ilk olarak hangi bölüm tarafindan talep edildi ise ona gelmektedir. Fatura, talepte bulunan kişi, ilgili bölümün direktörü ve genel müdür tarafından onaylanarak muhasebe bölümüne iletilmektedir.

Uygun Olan Kontrol Ve Öneriler: Faturanın uzun onay süreçlerinden geçmesi faturanın geç kaydedilmesine veya kaybolmasına neden olabilir. Mükerrer fatura riski söz konusu olabilir.

Tüm mal ve hizmet alımlarındaki fatura sürecinde, faturanın doğrudan muhasebe bölümüne gelmesi, satın alma bölümünün faturayı hiç görmemesi önerilmektedir.

Ek olarak kontrol ve onaylara sipariş ve teslim alma aşamalarında yoğunlaştırılması sağlanmalıdır. Fatura geldikten sonra yapılacak kontrollerin çok fazla anlamı yoktur. Eğer önceki aşamalar sağlıklı bir şekilde yürütülürse faturaların onay sürecinden geçmesine gerek kalmayabilir.

Soru 2: Fatura girişi sırasında üçlü karşılaştırma yapılarak sipariş-irsaliye-fatura bilgileri eşleştiriliyor mu?

İşletmede Var Olan Durum: Ticari mal alımları ile ilgili fatura giriş işlemleri muhasebe bölümü tarafından yapılmaktadır. E-faturaların otomatik girişi olmaktadır. Ek olarak E-fatura mükellefi olmayan satıcılar için sistemden manuel fatura girişi yapılmaktadır.

Fatura girişi yapılırken sistem tarafindan fatura, irsaliye, sipariş formu ve mal kabul formu eşleştirilmektedir. $\mathrm{Bu}$ aşamada hem dip toplam hem de satır bazında eşleştirme yapılmaktadır.

Sistemde fatura ile mal kabul işlemleri eşleştirilmekte ve fatura sistem üzerinden kapatılmaktadır. Sistemin arka planında her gün periyodik olarak satın alma faturaları ile mal kabul ve irsaliye eşleştirilmektedir. Eşleşmeyen faturalar her gün belirlenmektedir.

Ticari mal dışındaki diğer mal ve hizmet alım türlerinde üçlü karşılaştırma yapılmamaktadır.

Uygun Olan Kontrol ve Öneriler: Fatura girişi sırasında muhasebe bölümü gerekli tüm kontrolleri yapmalıdır. Bu kontrollerde;

- Teslim alınan malların siparişi verilen mallar olduğu,

- Malların birim fiyatının aynı olduğu,

- Faturadaki miktarın teslim alınan miktar ile aynı olduğu,

- Faturanın bu bilgilere uygun gönderildiği teyit edilmelidir.

Yapılan bu işlemlerde manuel işlem gerçekleştirilmemeli, faturalaştırma otomatik olarak yapılmalıdır. 
Ticari ürünler için uygulanan sürecin, diğer alım gruplarına da yaygınlaştırılması önerilir.

Soru 3: Siparişte yer alan birim fiyat ile faturada yer alan birim fiyatın işletme aleyhine farklı olması durumunda, sistem üzerinde otomatik fiyat farkı faturası düzenleniyor $\mathrm{mu}$ ?

İşletmede Var Olan Durum: Ticari mal alımları ile ilgili oluşan fiyat farkları muhasebe bölümü tarafından takip edilmektedir. Fiyat farkı söz konusu olması halinde, ilgili satın alma müdürü’nden onay alınarak fiyat farkı faturası düzenlenmektedir. İşletme hatasından kaynaklanan ve fatura düzenlenmeyen fiyat farkları ay sonu ilgili ürünün maliyetine aktarılmaktadır.

Ticari mal dışındaki diğer mal ve hizmet alım türlerinde üçlü karşılaştırma yapılmadığı için iade ve fiyat farkı faturaları otomatik bir şekilde kesilmemektedir. Fiyat farkları, mal ve hizmeti talep eden bölümün faturayı kontrolü aşamasında tespit edilmektedir. İlgili bölüm, fiyat farkı faturası kesilmesi gerekiyor ise muhasebe bölümüne bilgi vermektedir.

Uygun Olan Kontrol Ve Öneriler: Sipariş ile fatura arasında oluşan fiyat farklarına ilişkin sistem üzerinden otomatik fiyat farkı faturası düzenlenmesi sağlanmalıdır.

Ticari mal dışındaki mal ve hizmet alımlarındaki fiyat farkı süreci o alımı yapan kişi ya da birim tarafından yürütülmemelidir. Sipariş ve fatura birim fiyatı arasında işletme aleyhine meydana gelen farklar için otomatik fiyat farkı faturası kesilmesi önerilir.

\subsubsection{6. Ödeme}

Soru 1: Ödeme süreci nasıl işlemektedir?

İşletmede Var Olan Durum: Ticari mal alımı yapılan satıcılara vade geldiğinde havale yoluyla ödeme yapılmaktadır. Cari kartlara vade bilgisi tanımlanmıştır. Diğer alımların yapıldığı satıcılara ise fatura bazlı ödeme yapılmaktadır.

Muhasebe bölümü tarafindan sistemden ödeme listesi çekilir. Liste, excel dosyası halinde maille ilgililere gönderilmektedir. Satın alma bölümü ve diğer mal ve hizmet alımı yapan bölümler tarafından verilen bütçeye göre ödeme listesi kontrol edilerek gerekli ekleme ya da düzeltmeler yapılmaktadır. Ödeme listesi en son finans bölümüne iletilerek, ödeme işlemleri gerçekleşmektedir.

Ödeme listeleri finans direktörü, genel müdür ve yönetim kurulu üyesi tarafindan onaylanmaktadır.

Uygun Olan Kontrol ve Öneriler: Ödeme listesini muhasebe bölümü’nün değil, finans bölümü'nün sistemden çekmesi daha uygun olacaktır. Çeşitli ödeme sistemleri kullanılarak bu süreci otomatik hale getirmek mümkündür. 
Soru 2: Ödemelere ilişkin muhasebe kayıtları uygun şekilde atılıyor mu?

İșletmede Var Olan Durum: Ödemelerin muhasebe kayıtları finans bölümü tarafindan yapılmaktadır.

Uygun Olan Kontrol Ve Öneriler: Bankalarla entegrasyonun sağlanması bu alandaki en iyi uygulamadır. Entegrasyonun sağlanamaması durumunda muhasebe kayıtlarını muhasebe bölümü'nün atması ve finans bölümü tarafından kontrol edilmesi önerilir. midır?

Soru 3: Satıcı hesaplarının açılmasına yönelik uygun bir yetkilendirme yapılmış

İşletmede Var Olan Durum: Tüm alımlar ile ilgili cari kartlar satın alma bölümünde çalışan personeller tarafından açılmaktadır. Herhangi bir yetki kısıtlaması bulunmamaktadır. Başka bölümlerden talepler excel formatında bir form gelmekte ve satıcıya ait bilgiler (ismi, iban no, vergi no vs.) yer almaktadır. Gelen bilgiye göre ERP programında cari hesap açma işlemi yapılmaktadır.

Uygun Olan Kontrol Ve Öneriler: Satıcı cari hesaplarının satın alma bölümü tarafından açılması doğru bir uygulama değildir. Satıcı hesabı açma yetkisinin muhasebe bölümü'ne devredilmesi daha uygun olacaktır.

Soru 4: Satıcı hesabı açılmadan önce gerekli belgeler temin ediliyor mu?

İşletmede Var Olan Durum: Satıcı kartı açılmadan önce herhangi bir değerlendirme yapılmamaktadır. satın alma bölümü’ne diğer bölümlerden gelen talepler için bir form doldurulmaktadır ancak ekinde herhangi bir belge bulunmamaktadır. Benzer şekilde satın alma bölümü de kendi satıcılarına ilişkin bir dokümantasyon yapmamaktadır.

Uygun Olan Kontrol Ve Öneriler: Çalışılmaya karar verilen bir satıcı için cari hesap açmadan önce satıcı işletmeye ait bazı belgeler talep edilmeli ve satıcı hakkında ön araştırma yapılmalıdır. İmza sirküleri, vergi levhası gibi evraklar talep edilebilir. Bu evraklar mali işler bölümü tarafindan arşivlenmelidir.

\section{SONUÇ}

Çalışmamızda işletmenin satın alma ve ödeme döngüsündeki eksiklikler, yapılan öneriler ile beraber detaylı olarak anlatılmış olup özetle aşağıdaki şekildedir:

- Satın alma sürecinde görevlerin ayrılı̆̆ ilkesine aykırı durumların var olması,

- Satın alma sürecine ilişkin herhangi bir prosedür veya yönetmelik olmaması,

- $\quad$ Satın alma sürecinin ERP mantığında tam olarak otomatik ve diğer süreçlerle entegre bir şekilde yürütülmemesi,

- $\quad$ Sisteme uygun erişim tanımlamalarının tam yapılmaması,

- Satın alma ile ilgili bütçe programında aksaklıkların olması,

- Satın alma talebinin oluşturulması ve onaylanması aşamasında eksikliklerin bulunmas1,

- $\quad$ Teklif alma ve değerlendirme sürecinin sistem kapsamı dışında yürütülmesi, 
- Siparişlerin mal teslimi sırasında ve sonrasında oluşturulduğu durumların var olmas1,

- $\quad$ Sipariş onayının sözlü olarak yapıldığı durumların var olması,

- $\quad$ Siparişlerin sözlü olarak satıcılara bildirildiği durumların var olması,

- $\quad$ Sözleşmelerin sistem üzerinde arşivlenmemesi,

Çalışma ile ERP sisteminin, işletme için ne kadar önemli olduğu yapılan uygulama ile anlatılmaya çalışılmıştır. Çalışmanın uygulama bölümünde açıklanan öneriler doğrultusunda hem perakende sektöründe faaliyet gösteren işletmelerin işleyişine katkıda bulunması, hem de ilgili çalışma alanlarında araştırma yapacak kişi ya da kurumlara literatür ve metodoloji yönüyle fikir vermesi ümit edilmektedir.

\section{KAYNAKLAR}

Aydın, Serkan (2007), "ERP Ve Başarısızlık Nedenleri”, Yüksek Lisans Tezi, Balıkesir Üniversitesi F.B.E.

Aydoğan, Enver (2008), “Kurumsal Kaynak Planlaması”, TSA Dergisi, ss.107-118.

Bayraktar, Erkan - Efe, Mehmet (2006), "Kurumsal Kaynak Planlaması ve Yazılım Seçim Süreci”, Selçuk Üniversitesi S.B.E Dergisi, Sayı 15. ss. 690-709

Demirci, Erdal (2017), "Aile şirketlerinin Kurumsallaşma Düzeyi ile Kurumsal Kaynak Planlaması (KKP) Yazılımı Kullanımı Arasındaki İlişkilerin İncelenmesi: Rize Bölgesi’nde Bir Uygulama”, Yüksek Lisans Tezi, RTÜ Üniversitesi S.B.E.

Gelinas, Jr. Ulric - Dull, Richard (2008), "Accounting Information Systems", Seventh Edition, USA.

Karagöz, Erdem - Yıldız, Gürkan - Uzun, Ömer - Özaygün, Mustafa (2014), “Kurumsal Kaynak Planlaması ve Uygulaması”, Lisans Tezi, İstanbul Aydın Üniversitesi.

Karateke, Tuğçe (2016), "Bir Tekstil Firmasında Analitik Hiyerarşi Süreci ile Kurumsal Kaynak Planlaması Yazılımı Seçimi”, Yüksek Lisans Tezi, Gazi Üniversitesi Bilişim Enstitüsü.

Keçek, Gülnur - Yıldırım, Esra (2010), "Kurumsal Kaynak Planlama Sisteminin Analitik Hiyerarşi Süreci ile Seçimi: Otomotiv Sektöründe Bir Uygulama”, Süleyman Demirel Üniversitesi İ.İ.B.F Dergisi, Cilt 15, Sayı 1. ss. 193-211.

Klaus, Helmut - Rosemann, Michael - Gable.G. Guy (2000), “What is ERP?”, Information System Frontiers, Queensland University of Technology, Brisbane, Australia.

Polat, Kübra, Fatma (2013), “ERP Sistemleri ve Raporlama Teknikleri”, Yüksek Lisans Tezi, Haliç Üniversitesi F.B.E.

Yıldız, Selami, Mehmet - Akaydın, Ahmet (2012), "Kurumsal Kaynak Planlaması Sistemine Geçiş Yapan Endüstriyel Bir İşletmede Yazılımın Kurulum Süreci ve Yaşanılan Değişimler", Muhasebe ve Vergi Uygulamaları Dergisi, Cilt:5, Sayı:1, ss. 1-20. 
Yontar, Emel (2014), "ERP Kurulum Sürecinin Modellenmesi ve Tarım Makine Sanayide

Uygulanması", Yüksek Lisans Tezi, Kırıkkale Üniversitesi F.B.E.

http://thalesbilisim.com/malzeme-ihtiyac-planlamasi/, ( 08.03.2019).

https://sdmodulunegiris.com/satis-ve-dagitim-modulu-ne-yapar/, (09.03.2019).

http://thalesbilisim.com/insan-kaynaklari-yonetimi/ , (30.03.2019). 
